\title{
МИШЕНЬ-ОРИЕНТИРОВАННЫЙ ПОИСК ИНГИБИТОРОВ ВИРУСА SARS-COV-2
}

\section{О.И. Яровая', Д.Н. Щербаков², С.С. Борисевич³, Н.Ф. Салахутдинов}

${ }^{1}$ Новосибирский институт органической химии им. Н.Н. Ворожцова СО РАН, 630090, Россия, г. Новосибирск, пр. Лавреньева, 9.

${ }^{2}$ Федеральное Бюджетное Учреждение Науки Государственный Научный Центр

Вирусологии и Биотехнологии «Вектор» Роспотребнадзора, 630559, Россия, Новосибирская обл., р.п. Кольцово.

зУфимский институт химии УФИЦ РАН, 450054, Россия г. Уфа, проспект Октября, 71.

DOI: 10.19163/MedChemRussia2021-2021-208

E-mail:000@nioch.nsc.ru

Глобальная пандемия новой коронавирусной инфекции 2019 года (COVID-19), вызываемой вирусом SARS-CoV-2, началась в китайском городе Ухань в декабре 2019 года и с тех пор распространилась по всему миру. На сегодняшний день успешная разработка вакцин проводится сразу в нескольких ведущих вирусологических и научно-исследовательских центрах, и массовая вакцинация уже началась в России и по всему миру. Другое важное направление борьбы с вирусными инфекциями - применение специфических химиотерапевтических агентов, направленных на подавление репликации вируса в клетке хозяина. Использование противовирусных препаратов на ранней стадии развития болезни может существенно снизить вирусную нагрузку на организм и значительно уменьшить развитие осложнений, вызванных инфекционной болезнью. Каждый этап жизненного цикла вируса может быть потенциальной мишенью для лекарственной терапии. Перспективные мишени для лекарств включают неструктурные белки, например, 3-химотрипсин-подобная протеаза, папаин-подобная протеаза, РНКзависимая РНК-полимераза или поверхностные белки вируса.

Нашим коллективом исследователей разработаны подходы к мишень-ориентированному поиску новых химических соединений, влияющих на важные этапы жизненного цикла вируса SARS-CoV-2. С целью поиска агентов, активных на ранней стадии вирусной репликации, нами разработана псевдовирусная система, имеющая на своей поверхности гликопротеин вируса SARS-CoV-2. С использованием этой системы нами обнаружено два класса соединений, перспективных в качестве эффективных ингибиторов входа вируса. Нами разработана тест система, позволяющая проводить изучение активности синтезированных веществ в отношении основной протеазы. В качестве препаратов сравнения использовались дисульфирам и эбселен. Для оценки эффективности каждого из потенциальных ингибиторов создана флуоресцентная тестовая система. В настоящий момент нами обнаружены соединения, активные в отношении основной протеазы в микромолярной и субмикромолярной концентрации.

Работа выполнена при финансовой поддержке Российского фонда

фундаментальных исследований в рамках проекта № 20-04-60038.

$$
-208-
$$

